\title{
Economic and Social Rights: The Role of Courts in China
}

\author{
RANDALL PEERENBOOM (裴文睿)*
}

\section{TABLE OF CONTENTS}

I. INTRODUCTION ....

II. GLOBAL TRENDS: THE INCREASED SALIENCE OF ESR ….................................... 306
A. Legitimacy Concerns
B. Competence Concerns
C. The Limits of Litigation.

III. BACKGROUND CONDITIONS: A COMPARISON OF CHINA AND

SOUTH AFRICA

IV. TOWARD A CONSTRUCTIVE ROLE FOR CHINESE COURTS IN IMPLEMENTING ESR .

V. CONCLUSION

\section{INTRODUCTION}

Compared to the average lower-middle income country, China has done relatively well on most social and economic indicators. ${ }^{1}$ Chinese

* Professor of Law, La Trobe University; Associate Fellow, Centre for Socio-Legal Studies, Oxford University; rpeerenboom@gmail.com. The author thanks Otto Malmgren and the participants at the 2010 Beijing International Conference on Human Rights for their insightful comments.

1. See United Nations, Econ. \& Soc. Council (“ECOSOC”), Implementation of the International Covenant on Economic and Social Rights ("ICESCR"), Report Submitted by of the People's Republic of China, Addendum, U.N. Doc. E/1990/5/Add.59 (Mar. 4, 2004). See also RANDAll PeEREnBoom, Social and Economic Rights, Law and Order, Women's Rights, and Cultural Rights, in CHINA MODERNIZES: THREAT TO THE WEST OR MODEL FOR THE REST? (2007) (showing that China outperforms the average country in its lower-middle income class on most human rights measures and indicators of human well-being, with the notable exception of civil and political rights.) Despite relative progress, there are wide regional differences and many specific areas in need of substantial improvement. See id. 
courts however have generally played a limited, and rather ineffectual role in implementing economic and social rights ${ }^{2}$ (ESR). ${ }^{3}$

Not surprisingly, one of the concerns flagged by the Committee for Economic, Social and Cultural Rights (CESRC) was the extent to which

2. See Philip Alston, Putting Economic, Social, and Cultural Rights Back on the Agenda of the United States, (N.Y.U. Sch. of Law Center for Human Rights and Global Justice, Working Paper No. 09-35, 2009), available at www.chrgj.org/publications/docs/wp/ Alston\%20Spring\%2009.pdf (discussing those differences); Katharine G. Young, The Minimum Core of Economic and Social Rights: A Concept in Search of Content, 33 YALE J. INT'L L. 113 (2008).

3. See generally Fu Yulin \& Randall Peerenboom, A New Analytical Framework for Understanding and Promoting Judicial Independence in China, in JUDICIAL INDEPENDENCE IN CHINA: LESSONS FOR GLOBAL RULE OF LAW PROMOTION 112-16 (Peerenboom ed., 2010) (discussing the role of the courts in enforcing ESR); Randall Peerenboom \& He Xin, Dispute Resolution in China: Patterns, Causes and Prognosis, 4 E. Asian L. REv. 1 (2009) (discussing the same); ChINA ModERnizes, supra note 2, 136-37 (on the role of the courts in protecting the right to education); WANG LEI, Xuanzi Xianfa [To Choose Constitutional LaW] (2003); Yu Meisun, Cong Jiaoyubu Dang Beigao de Liangan, Kan Zhaosheng Zhidu Chuangxin de Poqiexing [On the Exigency of Renovating the College Recruiting System, Judging From the Two Cases Where the Ministry of Education is the Defendant], EPOCHTIMES.COM (China), (Apr. 23, 2004), http://www.epochtimes.com/gb/4/4/23/n519496.htm; Xia Chunli, Migrant Children and the Right to Compulsory Education in China, 7 AsiA-PAC. J. HuM. RTS. \& L. 29 (2006); Thomas E. Kellogg, Constitutionalism with Chinese Characteristics? Constitutional Development and Civil Litigation in China, 7 INT'L J. CONST. L. 215 (2009) (discussing the somewhat more positive but still limited role of the courts in combating various forms of discrimination); Timothy Webster, Ambivalence and Activism: Employment Discrimination in China, 44 VAND. J. TRANSNAT'L L. 643 (2011) (discussing rise of antidiscrimination cases since the passage of the Employment Promotion Law in 2007); Orianne Yin Dutka, Turning A Weapon Into A Shield: Using The Law To Protect People Living With HIV/AIDS In China From Discrimination, 38 Colum. HuM. RTS. L. REV. 421 (2007). On the role of the courts in labor disputes, see RoN BROWN, FOUND. FOR LAW, Justice \& SOC'Y, Rule OF LAW IN CHINA: CHINESE LAW AND Business-ChinA LABOR DISPUTE RESOLUTION (2008), available at http://www.fljs.org/uploads/documents/Brown \%231\%23.pdf (labor disputes increased from under 20,000 in 1994 to over 300,000 in 2006; most are resolved through arbitration, although there were over 120,000 litigation cases in 2005, of which one-third were settled through judicial mediation).

See also Yang Su \& Xin He, Street as Courtroom: State Accommodation of Labor Protest in South China, 44 LAW \& SOC'Y REV. 157 (Mar. 2010) (discussing the extralegal role of the courts in responding to worker claims in the wake of insolvencies resulting from the global recession). On environmental litigation, see BIE TAO, PUBLIC InTEREST ENVIRONMENTAl Litigation [HuAnjing Gongyi Susong], (2007); Gao Jie, Natural Res. Def. Council-China Program, Environmental Public Interest Litigation and the Vitality of Environmental Courts: the Development and Future of Environmental Courts in China, available at http://www.greenlaw.org.cn/files/reports/GaoJieEPCourts_En.pdf (discussing creation of special environmental courts and more permissive standing rules in some jurisdictions that allow NGOs to bring suit, and noting that environmental civil cases increased from 96 to 1509 from 1998 to 2008, while criminal suits rose from 1912 to 10,075 during the same period); Rachel Stern, On the Frontlines: Making Decisions in Chinese Civil Environmental Lawsuits, 32 LAw \& PoL'y. 79-103 (2010); Rachel Stern, From Dispute to Decision: Suing Polluters in China, CHINA Q. (forthcoming June 2011) (noting that the "vast majority of environmental disputes are handled through governmentbrokered deals, private concessions or simply when plaintiffs give up and go away”). 
ESR could be invoked before the courts. ${ }^{4}$ In its Concluding Remarks, the committee specifically urged China "to ensure that legal and judicial training takes full account of the justiciability of the rights contained in the Covenant and promotes the use of the Covenant as a source of law in domestic courts." 5

This Article considers what the role of the courts could and should be in implementing ESR in China. Part II surveys recent global developments giving greater bite to economic and social rights, as well as some of the

4. See United Nations, ECOSOC, Comm. on Econ., Soc. and Cultural Rights, Implementation of the ICESCR, List of Issues to be Taken Up in Connection with the Consideration of the Initial Report of the People's Republic of China Concerning the Rights Covered by Articles 1-15 of the ICESCR, I 1, U.N. Doc. E/C.12/Q/CHN/1 (June $7,2004)$. The role of the courts was the first issue listed. Id. In addition, the CESCR asked for specific cases involving non-discrimination against women, minors, persons with disabilities and the elderly, as well as statistics on the number of labor cases brought by the All China Federation of Trade Unions. Id. at 9ף 7, 22. Although China’s response did not provide complete statistics, the government did respond to the general question about the justiciability of the treaty by stating:

All the human rights and associated institutions specified in the [ICESCR] are provided for in the basic laws and regulations of the People's Republic of China. They are enforceable and can by and large meet the needs of Chinese court proceedings. The principles and spirit of the Covenant, for all practical purposes, are reflected in China's judicial system, namely, fulfilling the requirements of the Covenant by invoking domestic laws to protect citizens’ economic, social and cultural rights.

See United Nations, ECOSOC, Comm. on Econ., Soc. and Cultural Rights, Implementation of the ICESCR, Consideration of Reports Submitted by States Parties in Accordance with Article 16 of the ICESCR, Replies by the People's Republic of China, U.N. Doc. HR/CESCR/NONE/2004/10; ESCOR, 34th Sess., (Apr. 25-May 13, 2005). Moreover, the government's response, while mainly emphasizing legislation and government policies, did contain a few examples of discrimination cases. See id.

5. See United Nations, ECOSOC, Comm. on Econ., Soc. and Cultural Rights, Implementation of the ICESCR, Consideration of Reports Submitted by States Parties in Accordance with Article 16 and 17 of the Covenant, Concluding Observations, People's Republic of China (including Hong Kong and Macao), I 42, U.N. Doc. E/C.12/1/Add. 107 (May 13, 2005) (the committee drew "the attention of the State party to general comment No. 9 on the domestic application of the Covenant and invite[d] the State party to include information concerning case law on the application of the Covenant in its next periodic report”). China's second report, submitted in June 2010, so far only contains the core report, rather than the article-by-article treaty-specific report. The core report is a comprehensive if brief and superficial description of the legislative and legal framework, including a description of the legislature, courts, police and other institutional components of the legal complex. Whether the treaty-specific part will provide the detailed information about the role of the courts requested by the CESCR remains to be seen. See United Nations, Econ. \& Social Council, Comm. on Econ., Soc. and Cultural Rights, Implementation of the ICESCR, Second periodic reports submitted by States parties in accordance with articles 16 and 17 of the Covenant, People's Republic of China, U.N. Doc. E/C.12/CHN/2 (June 30, 2010), available at http://www2.ohchr.org/english/bodies/cescr/future.htm. 
main controversies, debates, and approaches to promoting, protecting, and fulfilling ESR, with particular attention to the role of the courts. Part III provides a general introduction to the social, legal, political, and economic context in China, and contrasts the situation in China with South Africa-one of the global leaders in judicial implementation of ESR. The overall environment in China is, if not hostile, at least not promising for a robust role for the courts in protecting ESR. Nevertheless, there is still some room for the courts to play a positive role in implementing ESR. Part IV provides some suggestions regarding the way forward, suggesting that what is needed is an approach that considers all factors: (1) absolute minimums and core rights; (2) the level of development nationally, regionally and locally; (3) community consensus and popular opinions; (4) institutional constraints; and (5) the role of courts within the Chinese constitutional structure and polity. Part V concludes.

\section{GLOBAL TRENDS: THE INCREASED SALIENCE OF ESR}

Although civil and political rights still receive more attention, the global salience of ESR has been increasing. The International Covenant on Economic, Social and Cultural Rights (ICESCR), passed in 1966, has now been signed by sixty-nine states and ratified by $160 .^{6}$ The Optional Protocol to the ICESCR, adopted on December 8, 2010, has given a further boost to ESR. The Protocol provides a mechanism for the CESRC to hear complaints from individuals, groups or other states. Although it has yet to enter into force, it has already been signed by thirty-five states and ratified by two.

There has also been a change in attitudes. Whether ESR are indeed "rights" is still debated, but less so. ${ }^{8}$ It is also now generally accepted that it is not possible to draw a sharp line between civil and political

6. Int'l Covenant on Econ., Soc. \& Cultural Rights, Dec. 16, 1966, 993 U.N.T.S. 3 [hereinafter ICESCR]; Barbara Stark, Economic, Social, and Cultural Rights: International Covenant on Economic, Social, and Cultural Rights, in 2 ENCYC. OF HuM. RTS. 88, 93 (David P. Forsythe ed., 2009).

7. Arne Vandenbogaerde \& Wouter Vandenhole, The Optional Protocol to the International Covenant on Economic, Social and Cultural Rights: An Ex Ante Assessment of its Effectiveness in Light of the Drafting Process, 10 Hum. RTS. L. REV. 207, 214, 220 (2010); Optional Protocol to the ICESCR, G.A. Res. 63, U.N. Doc. A/RES/63/117 (Dec. 10, 2008), available at http://treaties.un.org/doc/Publication/MTDSG/Volume\%20I/Chapter\% 20IV/IV-3-a.en.pdf; Claire Mahon, Progress at the Front: The Draft Optional Protocol to the International Covenant on Economic, Social and Cultural Rights, 8 HuM. RTs. L. REV. 617, 618, 628 (2008).

8. See Alston, supra note 2, at 3 (suggesting that even the United States has now come to accept them as rights, although the "United States has played [and continues to play] a central role in discouraging and sometimes blocking the development of the concept of ESCR”). 
rights (CPR) and ESR: both sets of rights have negative aspects-limiting government action-and positive aspects-requiring state action and support; the realization of CPR also requires government expenditures, such as to hold elections, fund the judiciary, and legal aid centers; and both sets of rights are interdependent in the sense that neither can be fully realized without the other. ${ }^{9}$

The constitutional basis of ESR is also increasingly secure. Many new constitutions in "third wave" democracies have incorporated individual or comprehensive ESR, although the piecemeal approach remains more common. Most importantly for present purposes, regional tribunals and domestic courts have assumed a more prominent role in enforcing ESR. Social rights are now litigated directly and indirectly before the African Commission on Human Rights, Inter-American Commission of Human Rights, Inter-American Court of Human Rights, European Committee of Social Rights, and European Court of Human Rights. ${ }^{10}$ Among the jurisdictions in which social and economic rights have been deemed justiciable and judicially enforceable are Bangladesh, Colombia, Finland, Kenya, Hungary, Latvia, the Philippines, Switzerland, Venezuela, South Africa, Ireland, India, Argentina and even the United States. ${ }^{11}$ These

9. See, e.g., United Nations, ECOSOC, Comm. on Econ., Soc. and Cultural Rights, Report on its 4th Sess., Jan. 15-Feb. 2, 1990, Gen. Comment No. 2, International Technical Assistance Measures (Art. 22), ๆף 6, 9, U.N. Doc. E/1990/23 (Feb. 2, 1990) [Hereinafter Gen. Comment 2]; Airey v. Ireland, 2 Eur. Ct. H.R. (ser. A) at 315 (1979) ("While the Convention sets forth what are essentially civil and political rights, many of them have implications of a social or economic nature ... [T] [Te mere fact that an interpretation of the Convention may extend into the sphere of social and economic rights should not be a decisive factor against such an interpretation; there is no water-tight division separating that sphere from the field covered by the Convention.”). See also A. Eide, State Obligations Revisited, in 2 FoOd AND Human Rights in DEVELOPMENT: EVOlVING IsSUES AND EMERGING APPLICATIONS (Wenche Barth Eide \& Uwe Kracht eds., 2007).

10. See Aoife Nolan et al., The Justiciability of Social and Economic Rights: An Updated Appraisal 3-4 (N.Y.U. Sch. of Law Center for Human Rights and Global Justice, Working Paper No. 15) (2009), available at http://ssrn.com/abstract=1434944.

11. See id.; Diane A. Desierto, Justiciability of Socio-Economic Rights: Comparative Powers, Roles and Practices in the Philippines and South Africa, 11 AsIAN-PAC. L. \& PoL'y J. 114, 134, 137 (2009); Elizabeth Palmer, Protecting Socio-Economic Rights Through the European Convention on Human Rights: Trends and Developments in the European Court of Human Rights, 2 ERASMUS L. REV. 397, 398-99 (2009); Rory O’Connell, Social and Economic Rights in the Strasbourg Convention, in RULE OF LAW AND Fundamental Rights of Citizens: THE AMERICAN AND EUROPEAN CONVENTION ON HUMAN RighTS 3-4, 11 (2009), available at http://ssrn.com/abstract=1368722; David Weissbrodt, International Law of Economic, Social, and Cultural Rights: A U.S. Perspective, in ECONOMIC Rights In CANADA AND THE UNITED STATES 41, 53-54 (Rhoda E. HowardHassmann and Claude Emerson Welch, Jr. eds., 2006); Jill Cottrell \& Yash Ghai, The 
states represent a wide diversity in terms of regions, philosophical and cultural traditions, political systems, constitutional structures and levels of wealth, suggesting that some role for the courts in realizing ESR is possible in all states.

Nevertheless, ESR remain controversial. Among the many contested issues and debates, three issues stand out. The first issue is the nature of the state's obligation with respect to ESR, and the tension between the need to take immediate steps to realize some or all of them at least in part, and their ultimate full realization on a progressive basis over time. In contrast to the International Covenant on Civil and Political Rights (ICCPR), which imposes an immediate obligation on state parties to respect and ensure all such rights, the ICESCR infamously provides that each state party "undertakes to take steps ... to the maximum of its available resources, with a view to achieving progressively the full realization of the rights recognized in the present Covenant by all appropriate means, including particularly the adoption of legislative measures." ${ }^{2}$ The CESCR has interpreted this article to mean that although the State need not achieve the full realization of ESR immediately, it does have an immediate duty to construct a program or action plan, ${ }^{13}$ as China has done. ${ }^{14}$ States must also take "deliberate, concrete and targeted" steps "within a reasonably short time" after becoming a party to meet their obligations. ${ }^{15}$ Moreover, the CESCR will carefully scrutinize any "deliberately retrogressive measures," and insist that they be "fully justified by reference to the totality of the rights provided for in the Covenant and in the context of the full use of the maximum available resources." ${ }^{, 16}$ Nevertheless, this leaves states with considerable discretion in determining the means to realize ESR, the amount of resources to allocate to their realization, and ultimately the pace and extent of their realization.

Role of the Courts in the Protection of Economic, Social \& Cultural Rights, in ECONOMIC, Social and Cultural Rights in Practice: THE Role OF JudGes in IMPLEMENTing ECONOMIC, SOCIAL \& CULTURAL RigHTS 58, 71, 74 (2004).

12. ICESCR, supra note 6, art. 2(1).

13. United Nations, ECOSOC, Comm. on Econ. Soc., and Cultural Rights, Rep. on its 3d Sess., Feb. 16-24, 1989, Gen. Comment No. 1, Reporting by State Parties, ๆ 4, U.N. Doc. E/1989/22, E/C.12/1989/5 (Feb. 24, 1989) [hereinafter Gen. Comment 1].

14. See Info. Office of the State Council, Nat'l Human Rights Action Plan OF ChINA (2009-2010) (effective Apr. 13, 2009), available at http://www.china.org.cn/ archive/2009004/13/content_17595407.htm (China).

15. United Nations, ECOSOC, Comm. on Econ. Soc., and Cultural Rights, Rep. on its 5th Sess., Nov. 26-Dec. 24, 1990, Gen. Comment No. 3, Nature of States Parties' Obligations (art.2 (1), I 2, U.N. Doc. E/1991/23, (Dec. 14, 1990) [hereinafter Gen. Comment 3].

16. Id. ๆ 9. 
A second and related issue is whether there are core rights or minimal standards that must be realized immediately, and whether a minimum core approach is the best way to go. The CESCR has stated:

[A] minimum core obligation to ensure the satisfaction of, at the very least, minimum essential levels of each of the rights is incumbent upon every State party. Thus, for example, a State party in which any significant number of individuals is deprived of essential foodstuffs, of essential primary health care, of basic shelter and housing, or of the most basic forms of education is, prima facie, failing to discharge its obligations under the Covenant .... By the same token, it must be noted that any assessment as to whether a State has discharged its minimum core obligation must also take account of resource constraints applying within the country concerned. Article 2 (1) obligates each State party to take the necessary steps "to the maximum of its available resources." In order for a State party to be able to attribute its failure to meet at least its minimum core obligations to a lack of available resources it must demonstrate that every effort has been made to use all resources that are at its disposition in an effort to satisfy, as a matter of priority, those minimum obligations. ${ }^{17}$

Even when resources are inadequate, states are obligated to ensure the widest possible realization of ESR given the circumstances, ${ }^{18}$ and to adopt "relatively low-cost" targeted programs during periods of economic recession or adjustment to protect the most vulnerable members of society. ${ }^{19}$

The notion of a minimum core has been subject to many criticisms, including that it is conceptually problematic; it is not workable in practice (what exactly does "every effort" to use "all resources" to meet the minimum core entail?); it is still too indeterminate, and requires context-specific balancing and decision making based on local circumstances; it targets only developing countries, or, if applied to developed countries as well, undermines the alleged universality of ESR since the minimal core in India will be considerably lower than in the United States; and it undermines efforts to achieve a more robust form of ESR. ${ }^{20}$ Accordingly, some ESR-friendly courts, such as in South Africa, have rejected the minimum core approach in favor of a reasonableness test that gives the government discretion even when it comes to the realization of the minimum core.

The third issue, or set of issues, and perhaps the most controversial, is the justiciability of ESR, the role of the courts in implementing ESR, and the proper standards to be applied in doing so. The CESCR has

17. Id. ๆ 10

18. Id. ๆ 11.

19. Id. I 12

20. See generally Young, supra note 2. 
noted, "The [ICESCR] contains no direct counterpart to ... the [ICCPR], which obligates States parties to, inter alia, 'develop the possibilities of judicial remedy.",21 It also acknowledged that the "right to an effective remedy need not be interpreted as always requiring a judicial remedy. Administrative remedies will, in many cases, be adequate and those living within the jurisdiction of a State party have a legitimate expectation, based on the principle of good faith, that all administrative authorities will take account of the requirements of the Covenant in their decisionmaking. Any such administrative remedies should be accessible, affordable, timely, and effective."22

Nevertheless, the CESCR has strongly urged states to provide judicial remedies:

[A] State party seeking to justify its failure to provide any domestic legal remedies for violations of economic, social and cultural rights would need to show either that such remedies are not 'appropriate means' ... or that, in view of the other means used, they are unnecessary. It will be difficult to show this and the Committee considers that, in many cases, the other means used could be rendered ineffective if they are not reinforced or complemented by judicial remedies. ${ }^{23}$

Administrative remedies alone are generally insufficient, and should be accompanied by some form of judicial review. ${ }^{24}$ Moreover, the CESCR has claimed that "there are some obligations, such as (but by no means limited to) those concerning non-discrimination, in relation to which the provision of some form of judicial remedy would seem indispensable in order to satisfy the requirements of the Covenant. In other words, whenever a Covenant right cannot be made fully effective without some role for the judiciary, judicial remedies are necessary." 25

More specifically, the CESCR has "made clear that it considers many of the provisions in the Covenant to be capable of immediate implementation," including: (1) Article 3, equal right of men and women to the enjoyment of all economic, social and cultural rights; (2) Article 7(a) (i), fair wages and equal pay for equal work; (3) Article 8, the right to form and join trade unions; Article 10(3), child labor; (4) Article 13, free primary education and other educational rights; and (5) Article 15(3), the freedom indispensable for scientific research and creative activity. ${ }^{26}$ Indeed, the Committee has asserted that "there is no Covenant

21. United Nations, ECOSOC, Comm. on Econ. Soc., and Cultural Rights, Gen. Comment No. 9, Domestic Application of the Covenant, 19th Sess., Nov. 16-Dec. 4, 1998, I 3, U.N. Doc. E/C.12/1998/23, (Dec. 3, 1998) [hereinafter Gen. Comment 9].

22. Id. $\uparrow 9$.

23. Id. 93.

24. Id. ๆ 9.

25. Id.

26. See id. ๆ 10; Gen. Comment 3, supra note 15, ๆ 5. 
right which could not, in the great majority of systems, be considered to possess at least some significant justiciable dimensions.,27

As noted, there is a growing global trend for ESR to be directly or indirectly justiciable. However, resistance remains strong, as the CESCR recognizes:

State practice is mixed. The Committee notes that some courts have applied the provisions of the Covenant either directly or as interpretive standards. Other courts are willing to acknowledge, in principle, the relevance of the Covenant for interpreting domestic law, but in practice, the impact of the Covenant on the reasoning or outcome of cases is very limited. Still other courts have refused to give any degree of legal effect to the Covenant in cases in which individuals have sought to rely on it. There remains extensive scope for the courts in most countries to place greater reliance upon the Covenant. ${ }^{28}$

Concerns about the justiciability of the courts fall into two categories: (1) general concerns about the legitimacy and competence of the court to handle ESR cases, and (2) the limits of litigation as a means to bring about the type of systemic changes needed to fully realize ESR. More specific concerns such as the proper standards for handling ESR casessuch as minimum core versus reasonableness standard-or whether ESR should be enforced directly or indirectly through civil and political rights. ${ }^{29}$ Although it is not possible to address the many specific issues here, a brief discussion of the general issues may be useful.

27. Gen. Comment 9, supra note 21, ๆ 10.

28. Gen. Comment 9, supra note 21, $\mathbb{1} 13$.

29. Compare James L. Cavallaro \& Emily J. Schaffer, Less as More: Rethinking Supranational Litigation of Economic and Social Rights in America, 56 HASTINGS L.J. 217 (2007) (favoring indirect approach), and Takele Soboka Bulto, The Indirect Approach to Promote Justiciability of Socio-Economic Rights of the African Charter on Human and Peoples' Rights, in HumAn Rights Litigation AND THE DOMESTICATION OF INTERNATIONAL Human RighTS STANDARDS IN Sub-SAHARAN AFRICA 135, (R.H. Murray ed., 2009), with Tara Melish, Rethinking the 'Less as More' Thesis: Supranational Litigation of Economic, Social and Cultural Rights in the Americas, 39 N.Y.U. J. INT'L L. \& POL. 171 (2006) (arguing in favor of the direct approach). See generally Nolan et al., supra note 10 (The indirect approach usually seeks to pursue ESR via reference to the principles of equality, non-discrimination or human dignity, or to the general principles of due process and fairness, or to the right to life, although there have also been cases based on freedom of expression and association, the right to privacy and personal integrity rights); O'Connell, supra note 11. See also Sandra Fredman, Human Rights Transformed: Positive Duties and Positive Rights, PuB. L. 498 (Autumn 2006) (arguing that the guiding principle for adjudication of the positive duties of the states should be reinforcement of democracy). 


\section{A. Legitimacy Concerns}

Legitimacy concerns come in two forms. The first reflects concerns about separation of powers and the relation between domestic courts and the legislature. The CESCR has rejected the common objection that implementation of ESR involve decisions about the allocation of resources which should be left to political authorities:

While the respective competences of the various branches of government must be
respected, it is appropriate to acknowledge that courts are generally already involved
in a considerable range of matters which have important resource implications. The
adoption of a rigid classification of economic, social and cultural rights which puts
them, by definition, beyond the reach of the courts would thus be arbitrary and
incompatible with the principle that the two sets of human rights are indivisible
and interdependent. It would also drastically curtail the capacity of the courts to
protect the rights of the most vulnerable and disadvantaged groups in society.

Nevertheless, ESR cases may raise serious resource-allocation issues that could have a significant impact on economic growth and social stability. Moreover, in most cases, courts do suffer from a democracy deficit relative to the legislature. However, the seriousness of this issue will depend on various local factors, including the constitutional structure, whether ESC are incorporated into the constitution, the power of the courts to engage in constitutional and judicial review, and the remedies available to the courts, which will depend to some extent on the level of development. Thus, while separation-of-powers issues suggest a more cautious approach in some circumstances, they do not preclude a role for the courts. A more case and context specific analysis is required.

A second legitimacy issue involves sovereignty concerns, and the relation between domestic legal-political systems and international and regional rights committees, tribunal and related bodies. There is always the worry that international law will usurp domestic policymaking space, and that decisions by far away international bodies, whose members are not elected by or directly accountable to domestic constituents, will encroach on state sovereignty. Indeed, several states, including the United States and Canada, opposed the Optional Protocol for the ICESCR, arguing inter alia that it is inappropriate for international bodies to interfere with governments' decision about socio-economic policy. ${ }^{31}$

30. Gen. Comment 9, supra note 21, 910.

31. See Nolan et al., supra note 10 , at 4 . The draft text provided various options "to address the different and sometimes complex proposals to limit the scope of a communications procedure to: (a) "core rights" or "minimum contents" of rights; (b) non discrimination; (c) serious violations of Covenant rights; and (d) "respect" and "protect" aspects of the rights, with an opt-out procedure allowing States to exclude "fulfill" aspects." United Nations, Human Rights Council, 6th Sess., Open-ended Working Group on an Optional Protocol to the ICESCR, 4th Sess., July 16-27, 2007, Draft Optional Protocol to 
Although the CESCR has been firm on several issues, including the need for judicial remedies, in its non-binding general comments and concluding comments, it has been careful to avoid imposing too detailed a plan for realizing ESR on state parties. For instance, in urging state parties to set specific goals for the reduction of infant mortality, child vaccination rates, the intake of calories per person and so on, it acknowledged that "global benchmarks are of limited use, whereas national or other more specific benchmarks can provide an extremely valuable indication of progress." 32 Given the potential legitimacy deficit, some scholars have sensibly cautioned that supranational litigation of ESR must be practiced in a manner respectful of non-legal contextual factors to be effective. It should be one element in an integrated strategy toward achieving meaningful social change, tied to broader advocacy strategies, and closely coordinated with social movements, media engagement and other forms of pressure. ${ }^{33}$

In short, while such concerns should not be dismissed lightly, given the relatively weak enforcement powers of the CESCR and most regional bodies, as well as a general trend to accept the encroachment of international law and human rights on state sovereignty, most states need not be overly concerned that their policymaking space will be excessively restricted by overreaching international bodies coercively enforcing robust versions of ESR. ${ }^{34}$ States certainly cede a great deal more

the ICESCR prepared by the Chairperson-Rapporteur, Catarina de Albuquerque, U.N. Doc. A/HRC/6/WG.4/2 (Apr. 23, 2007). On the duties to respect, protect and fulfill, see Henry Shue, Basic Rights (1996). See also Charles BeItz, The IDEA OF HuMAN Rights (2009).

32. Gen. Comment 1, supra note 13, ๆ 6.

33. Cavallaro \& Schaffer, supra note 29.

34. The degree of threat will vary by region, depending on many factors, including the powers of the regional body, the extent to which the decisions of the regional body are binding domestically, and the regional body's ESR jurisprudence. See Monica Feria Tinta, The Inter-American Court and the Role of National Courts in Protecting SocioEconomic Rights, Paper Presented at the Foundation for Law, Justice and Society (2008) (on file with author). Thus, there may be more grounds to worry in Latin America than in Asia. See id. In Latin America, the American Convention on Human Rights is considered national law in most countries and the Inter-American Court on Human Rights has more aggressively sought to bring about social transformation through an ambitious jurisprudence of ESR that interprets the right to life to encompass the right to a "dignified existence" and a "decent life." See id. In contrast, there is no regional human rights convention in Asia, and the human rights arm of ASEAN remains weak and apparently committed to the sovereignty respecting "diplomacy of accommodation." See id. Moreover, the indirect approach may be more effective in Europe and the U.S. where there is a general antipathy to ESR and strong philosophical and jurisprudential support for CPR than in China and 
autonomy over economic and development policymaking when they join the World Trade Organziation. In any event, such concerns do not preclude some role for domestic courts in ESR cases. ${ }^{35}$

\section{B. Competence Concerns}

Even assuming domestic courts are legitimate venues for implementing ESR, whether the courts have the competence to do so remains contested. Nolan et al. provide a useful breakdown, and point by point refutation, of competency concerns:

(i) the courts lack the information required to deal with social and economic rights; (ii) the judiciary lacks the necessary expertise, qualification or experience to deal with social and economic rights issues; (iii) the courts are incapable of dealing successfully with 'polycentric' tasks, such as those entailed by adjudication involving social and economic rights; and (iv) the courts lack the necessary tools and remedies to deal effectively with social and economic rights. ${ }^{36}$

As with legitimacy concerns, the competency concerns should not be dismissed lightly. But closer analysis and the ever-accumulating body of experience with domestic courts implementing ESR demonstrate that such concerns need not preclude some constructive role for domestic courts in implementing ESR.

Rather, the competency concerns, like the legitimacy concerns, suggest that the Court should adopt a cautious approach. It should take steps to mitigate these concerns and take local circumstances into consideration when deciding cases and formulating remedies. For example, regarding the information problem, some courts have responded to the information problem by inviting amicus curiae filings. In South Africa, the court "routinely issues orders to the parties prior to the hearing, during the hearing, or even during post-hearing deliberations that invite one or both of the parties to make submissions of reports, studies, or other factual

other Asian countries. See id. See generally Andrea Durbach et al., 'A Tongue But No Teeth?': The Emergence of a Regional Human Rights Mechanism in the Asia-Pacific, 31 SYDNEY L. REV. 211 (2009).

35. Nor would it preclude other positive roles for international law. See Susan Harris Rimmer, Assessing the Relevance of the International Legal Framework in Claiming Economic and Social Rights, in Human Rights AND Social Policy (Ann Neville ed., 2010) ("International human rights law can influence domestic courts in other ways than by giving rise directly to litigation, for example as a tool for statutory interpretation; to influence the development of the common law; as a basis of judicial review in administrative law; in the exercise of judicial discretion; and as an indicia of contemporary standards and values and therefore relevant to the context in which the state's constitution should be interpreted and applied. Moreover, international treaties can form the basis of a wide suite of policy and budgetary tools.").

36. Nolan et al., supra note 10 , at 2. 
documentation for the justices to review. ${ }^{\text {"37 }}$ In some cases, courts may seek testimony from experts or even hold public hearings. Such measures clearly help, but they do not completely alleviate information concerns. Accordingly, courts may still in some cases have to deny relief to plaintiffs if they lack adequate information on a particular issue, as the South African Constitutional Court did in overturning the lower court's order for the state to provide infant formula to poor mothers. ${ }^{38}$

Similarly, courts can mitigate the legitimate fear that court decisions will have a negative impact on economic growth or in the extreme bankrupt the state by acknowledging the risk, tailoring their remedies, and more generally adopting a cautious approach. Again, the experience of the South African Constitutional Court is instructive. The Court has expressly acknowledged the problem: "[Courts] are ill-suited to adjudicate upon issues where the Court orders could have multiple social and economic consequences for the community. The Constitution contemplates rather a restrained and focused role for the Courts." 39 More importantly, it has responded "by deferring to the legislature where no clear violation of a right has occurred, by assuming as little traditionally legislative authority as possible regarding remedial program specifics, and by rejecting any form of unqualified rights that might otherwise call for non-discretionary remedies." 40

Courts have a variety of remedies at their disposal, including the award of monetary damages or reparation in-kind to individual parties. They may also "read in" additional protections in a legislative scheme to protect socially vulnerable groups. Additionally, they may issue declaratory orders noting a rights violation but leaving it to the state to devise a remedy, mandatory orders requiring specific actions to be taken or supervisory orders providing for ongoing supervision of government action by the court and/or requiring the relevant agency to report back within a set time-frame. ${ }^{41}$

37. Eric Christiansen, Adjudicating Non-Justiciable Rights: Socio-Economic Rights and the South African Constitutional Court, 38 Colum. Hum. RTs. L. Rev. 321, 351 (2007).

38. Minister of Health v. Treatment Action Campaign (No. 2) 2002 (5) SA 721 (CC) at para. 134 (S. Afr.), available at http://www.saflii.org/za/cases/ZACC/2002/15.pdf [hereinafter TAC].

39. Id. ๆ 38

40. Christiansen, supra note 37 , at 380-81.

41. Nolan et al., supra note 10 , at 19-20. 
There is a risk of judicial overarching and excessive judicial activism, with negative consequences for individual plaintiffs and the judiciary alike. Remedies that lack popular support or are too costly are likely to go unenforced. ${ }^{42}$ Overly ambitious judicial decisions may invite a backlash against the court, and undermine support for other ESR. Nevertheless, courts have the ability to mitigate the risk by adopting a restrained approach and carefully selecting their remedies.

\section{The Limits of Litigation}

One final general concern is that the focus on litigation is misguided in that litigation cannot address the main causes of poverty, inequality and ESR violations, which are systemic and tied in most countries to a neoliberal free-market ideology and the dismantling of the welfare state. ${ }^{43}$ At minimum, the focus should be on good policy design and effective policies that promote sustainable and equitable growth. More ambitiously, greater "thought work" is required to replace the dominant ideology with a more progressive one.

This is a necessary caution given the recent trend toward judicialization, the court-centric approach of the rule of the law promotion industry, and the CESCR emphasis on judicial remedies. In many developing countries, the judiciary may be weak and overburdened. Nevertheless, in most countries, including China, ESR have been promoted primarily through government policies and implemented through political and administrative channels. ${ }^{44}$ Even advocates of a robust role for the courts allow that

42. Indian courts have been among the most active in promoting ESR - even though ESR are considered "directive principles" rather than justiciable fundamental rights in the constitution - by interpreting the right to life to include the right to a clean environment, food, suitable working conditions, emergency medical treatment and even free legal aid. See Jayna Kothari, The Role of the Courts in Enforcing Socioeconomic Rights: the Indian Experience, Conference Paper Presented at the Foundation for Law, Justice and Society (2008) (on file with author). In so doing, they have issued a series of far-reaching decisions with significant cost implications. Id. The right to food, for instance, was interpreted to entail the distribution of food grain and other basic commodities at subsidized prices, assistance to destitute households, and the provision of cooked midday meals to children in all government schools. Id. While the provision of midday deals has been relatively effective, the other remedies have encountered resistance in implementation. Id.

43. See generally Dianne Otto \& David Wiseman, In Search of "Effective Remedies": Applying the International Covenant on Economic, Social and Cultural Rights in Australia, 7 AUSTL. J. HUM. RTS. 5 (2001), available at http://www.austlii.edu.au/au/journals/AUJlH Rights/2001/2.html.

44. See e.g., State Council Info. Office, Progress in China's Human Rights in 2009 (Sept. 26, 2009) (China), available at http://news.xinhuanet.com/politics/2010-09/26/ c 12606421 3.htm (including a section judicial protection of rights). However, rather than a discussion of specific cases, that section emphasizes law and order concerns and criminal law issues (including the number of people arrested and convicted); new regulations to ensure that the police, procuracy and other legal complex actors are held accountable and cannot abuse 
litigation alone will not suffice to ensure the realization of ESR, and that litigation must be part of a broader strategy carried out on many fronts and in many venues. That does not mean however that the potentially positive role of the courts should be discounted or ignored.

\section{BACKGROUND CONDITIONS: A COMPARISON OF CHINA AND SOUTH AFRICA}

Dispute resolution of socio-economic cases has been characterized by: (1) notably less effective resolution than the vast majority of commercial cases; (2) a trend toward dejudicialization, in contrast to the judicialization of most commercial disputes-the government has steered socioeconomic disputes away from the courts toward other mechanisms such as administrative reconsideration, mediation, arbitration, public hearings and the political process more generally, when it became apparent that the courts lacked the resources, competence and stature to provide effective relief in such cases; ${ }^{45}$ (3) a sharp rise in mass-plaintiff suits, and subsequent attempts to limit such suits by both government and party entities and the judiciary itself; (4) an attempt to dismantle litigation support networks, including not only lawyers engaged in political cause lawyering (roughly, the pursuit of civil and political rights), ${ }^{46}$ but of "social cause lawyers" focusing on issues that lie closer to the core concerns reflected in $\operatorname{ESR}^{47}$ (5) a dramatic rise in letters, petitions, and social protests in response to the inability of the courts and other mechanisms to address adequately citizen demands and expectations; (6) a reallocation of resources toward the least well off members of society as part of a government effort to contain social instability and create a harmonious society, combined with a simultaneous increase in

their power; efforts to increase government transparency and legal aid; new rules to protect lawyers in carrying out their duties; and mediation. See id. The section on economic, social and cultural rights emphasizes government policies to mitigate the negative effects of the global economic recession, including efforts to create jobs, strengthen the social security system, and ensure (free) compulsory education through the ninth grade (which reportedly reached $99.7 \%)$. See id.

45. Randall Peerenboom, More Law, Less Courts: Legalized Governance, Judicialization, and Dejudicialization in China, (La Trobe Univ. Sch. of Law, Working Paper No. 2008/10, 2008), available at http://ssrn.com/abstract=1265147.

46. Stuart Scheingold \& Austin Sarat, Something to Believe: Politics, PROFESSIONALISM, AND CAUSE LAWYERING 3 (2004).

47. Randall Peerenboom, The Political Economy of Rule of Law in Middle-Income Countries: A Comparison of Eastern Europe and China 23-27 (Sept. 7, 2010) (unpublished paper), available at http://ssrn.com/abstract=1673581. 
targeted repression of potential sources of instability, including political dissidents, certain non-government organizations (NGOs), and the more aggressive muckraking segment of the media.

To better understand why social and economic cases have proven so difficult, it is useful to contrast the situation in China and South Africa. South Africa is generally considered to be a world leader in judicial implementation of ESR. ${ }^{48}$ Like China, South Africa is a middle-income country, albeit somewhat wealthier on a per capita basis. ${ }^{49}$ Both countries suffer from high levels of inequality, although the problem is more severe in South Africa. ${ }^{50}$ One of the key differences is the historical context. In South Africa, apartheid led not only to deprivation of CPR, but to severe poverty and inequality. The ANC came to power promising to address both political and economic issues, including social and economic inequality.

As a result, ESR were entrenched in the constitution, including the right to adequate housing, access to health care and emergency medical treatment, sufficient food and water, social security, basic education, including adult education, and an environment that is not harmful to health. ${ }^{51}$ Children were specifically provided the right to basic nutrition, shelter, basic health care services and social services. ${ }^{52}$ Moreover, the state was expressly charged with realizing ESR. Following the ICESCR, the constitution provides that the state must take reasonable legislative and other measures, within its available resources, to achieve the progressive realization of such rights. The state-including the legislature, executive, judiciary and all other organs-is required to respect, protect, promote, and fulfill the Bill of Rights, which includes ESR. ${ }^{53}$

48. See, e.g., Tumoi Murombo, Securing Environmental, Economic, Social and Cultural Rights (EESCRS) in Southern Africa: Challenges and Opportunities, (Sept. 21, 2009) (Working Paper), available at http://ssrn.com/abstract=1554204.; Cass R. Sunstein, Social and Economic Rights? Lessons from South Africa, (Univ. of Chi. Law Sch. John M. Olin Law \& Econ. Working Paper Series, No. 124, 2001), available at http://ssrn.com/abstract $=269657$.

49. South Africa's 2009 GDP per capita was approximately $\$ 5800$, compared to $\$ 3700$ for China. See WORLD BANK, WORLD BANK DEVELOPMENT INDICATORS, available at http:// data.worldbank.org/indicator/NY.GDP.MTP.CD.

50. South Africa's Gini coefficient in 2007 was .57 compared to .47 for China. See UNDP, Human Development Report 2007/2008-Fighting climate change: Human Solidarity in a Divided World, 282-83 (2007), available at http://hdr.undp.org/en/reports/ global/hdr2007-2008/.

51. S. Afr. CONST., 1996, arts. 24, 26-27, 29.

52. Id. art. 28.

53. Id. arts. 7(2), 8(1). 
The constitution also expressly provides individuals the right to access the court to protect their constitutional rights, ${ }^{54}$ with liberal standing rules that allow any individual or organization acting in the public interest to bring suit. ${ }^{55}$ Courts are mandated to adopt a purposive interpretation method that promotes the spirit as well as the letter of the law in rights cases. ${ }^{56}$ Courts are also provided broad remedial powers to grant "appropriate" relief. ${ }^{57}$ The Constitutional Court enjoys broad power, including the exclusive power to decide constitutional matters and the authority to decide whether acts of parliament are constitutional. Both constitutionally and in practice, the South African judiciary enjoys considerable independence. Moreover, unlike many developing countries, South Africa also had a reasonably strong and professional judiciary. More generally, there is broad support for the rule of law both among the citizenry and on the part of the government. In short, South Africa presents an extremely favorable context for pursuing ESR in the courts.

The situation in China, on the other hand, is much closer to the opposite end of the spectrum. The ability of Chinese courts to implement ESR is constrained by law, institutional design, political realities, ideological conflicts, and resource constraints. Although the PRC constitution does list a number of ESR, no rights in the constitution are directly justiciable absent implementing legislation, not even CPR. Moreover, in dramatic contrast to the powerful constitutional court in South Africa, there is no constitutional court in China.

Whereas South Africa is a liberal democracy in which the courts have actively protected CPR, China remains an effectively single-party socialist state with limited protection of CPR when the exercise of such

54. Id. art. 34 ("Everyone has the right to have any dispute that can be resolved by the application of law decided in a fair public hearing before a court or, where appropriate, another independent and impartial tribunal or forum.”).

55. "Anyone listed in this section has the right to approach a competent court, alleging that a right in the Bill of Rights has been infringed or threatened, and the court may grant appropriate relief, including a declaration of rights. The persons who may approach a court are- (a) anyone acting in their own interest; (b) anyone acting on behalf of another person who cannot act in their own name; (c) anyone acting as a member of, or in the interest of, a group or class of persons; (d) anyone acting in the public interest; and (e) an association acting in the interest of its members.” Id. art. 38.

56. Id. art. 39.

57. Id. art. (8)(3)(a) (providing that a court, "in order to give effect to a right in the Bill, must apply, or if necessary develop, the common law to the extent that legislation does not give effect to that right") (emphasis added). 
rights is deemed to threaten socio-political stability. ${ }^{58}$ While the PRC constitution provides for judicial independence in deciding cases, and courts are able to handle many cases independently, the CCP continues to make major policy decisions, and to exert an influence on the judiciary both indirectly and directly. ${ }^{59}$ Moreover, in comparison to the courts in South Africa, the courts in China are institutionally much weaker. The Chinese system is more akin to a parliamentary system, with the highest organ of state power being the National People's Congress. Given the legal system's civil law heritage, courts have relatively circumscribed powers. They cannot overturn acts of parliament, or even strike down administrative rules and regulations. ${ }^{60}$ Lower level courts have until recently been funded by the local government, ${ }^{61}$ with judges appointed by local people's congresses. This has led to local protectionism in some cases, where the courts favor economically important local actors, with negative consequences for individuals in labor and environmental disputes.

Further, unlike in South Africa, there is no clear popular mandate for the courts to play a leading role in transforming society. There are

58. South Africa ranks in the 66th percentile globally on Voice and Accountability (the World Bank's aggregate indicator of civil and political rights), whereas China ranks in the 5th percentile. Upper-middle income South Africa also outperforms lower-middle income China on all other indicators: by percentile rank, political stability (44th v. 30th), government effectiveness (68th v. 58th), regulatory quality (58th v. 38th), rule of law (56th v. 45th), and control of corruption (60th v 37th). See Daniel Kaufmann, et al., The Worldwide Governance Indicators: Methodology and Analytical Issues (The World Bank Development Research Group-Macroeconomics and Growth Team, Working Paper No. 5430, 2010), available at http://info.worldbank.org/governance/wgi/index.asp.

59. Judicial independence is a complicated topic, as simplistic assertions about the "lack of judicial independence" in China fail to capture a much more complex reality. The extent of independence depends on many factors, including the type of case, level of court and region. See generally Yulin \& Peerenboom, supra note 3. While judges enjoy the most independence in commercial cases, they also have may have adequate autonomy to decide many ESR cases independently, including labor and environmental cases. See, e.g., Stern, supra note 3, at 84-85 ("contrary to the conventional image of Chinese judges as bureaucratic automatons, pollution lawsuits suggest that judges enjoy a fluctuating degree of autonomy. In addition to practical issues (e.g., the fact that political elites cannot possibly weigh in on every decision), discretion stems from splotchy application of the law, legal silences, and the ambiguity of underlying political goals. Uncertainty about both legal principles and state priorities, in short, lends judges the political and legal cover to plausibly defend the decision they see fit.”). The problem in many ESR cases is not the lack of judicial independence, but that the courts are unable to resolve the dispute and provide an adequate remedy without reaching out to the government for assistance. See Peerenboom, supra note 45.

60. The courts have the power to review specific administrative acts but not abstract acts.

61. There has been a recent attempt to centralize funding. However, to what extent this new policy is being carried out remains unclear. See Zhongguo falü fazhan baogao (19792004), in CHINA LEGAL DEVELOPMENT REPORT (Zhu Jingwen ed., 2007). For centralized funding, see State Council Info. Office, China's Efforts and Achievements in Promoting Rule of Law, 7 CHINESE J. INT’L L. 513 (2008), available at http://chinesejil.oxfordjournals. org/content/7/2/513.full.pdf+html. 
fundamental disagreements about social policy and the future of China among the New Left and the New Right, socialists and neoliberals. Moreover, as noted, China has been relatively successful among developing states in reducing poverty and improving living standards. It has done so mainly through government policies and programs, with a greater role for political and administrative mechanisms to redress problems than for the courts.

The vast differences in local circumstances suggest that courts in different countries will and should play different roles in implementing ESR. While it would be unrealistic to expect courts in China to play as forceful a role in implementing ESR as in South Africa, Chinese courts may still play a positive role.

\section{TOWARD A CONSTRUCTIVE ROLE FOR CHINESE COURTS IN IMPLEMENTING ESR}

The fundamental guiding principle for the courts is to adopt an approach based on the three Cs: consultation, collaboration, and caution. Like most judges everywhere, most judges in China are realistic. They want to do their jobs as best they can, to follow the law, and at the same time, provide an adequate remedy where possible. Given the weak powers of the courts, shortcomings in the legal framework particularly with respect to individual remedies, and the lack of resources to address systemic socio-economic claims, cooperation with government agencies to resolve the immediate case is often the best, if not the only, option.

Chinese courts have a number of institutional mechanisms to facilitate consultation and cooperation. Most importantly, the party political-legal committee serves as an intermediary between government branches, and has the authority to resolve institutional conflicts. While many commentators fear an expanded role for political-legal committees would undermine judicial independence, there is little point denying their existence. On balance, it would be better to accept them as part of the China's living constitution and maximize their positive role while minimizing their negative impact in terms of judicial independence. Similarly, every court has an adjudicative committee of senior judges, headed by the court president. The court president often has a political background, and is well suited for negotiating responsive solutions with other government agencies. 
Chinese courts have already recognized the importance of working with, rather than against, the government to resolve ESR cases. ${ }^{62}$ In 2002, the SPC and the Ministry of Justice began promoting "grand mediation" (da tiaojie). ${ }^{63}$ Grand mediation is an attempt to bring all stakeholders together, including government and party officials, judges, civil organizations and citizens. Grand mediation operates under the leadership of the party and government, is guided by law and politics, takes justice as the main goal, and involves participation by all parties (dangzheng lingdao, zhengfa qiantou, sifa weizhu, gefang canyu) in $2002 .{ }^{64}$ It seeks to combine judicial mediation, people's mediation and administrative mediation. The involvement of government and party officials is intended to help address resource allocation issues and overcome political-economy obstacles, including interest-based resistance on the part of particularly strong actors and conflicts among different government entities, none of which wants to be the one liable for making good on the obligations of ESR.

For instance, when the global recession led many businesses to close shop, disgruntled workers took to the street in protest. In response, government officials and judges, acting under the authority of the recently established Social Stability Maintenance Office (an office under the political-legal committee) met the protesters in the street in an effort to mediate a settlement, thus transforming the streets into a courtroom. This "street as courtroom" approach is a result of the weak capacity of the legal system, including a restrictive and cumbersome regulatory

62. On the need for a cooperative approach to employment discrimination cases, see Webster, supra note 3, at 65 ("a problem as widespread as employment discrimination requires the coordinated efforts of courts, labor bureaus, local people's congresses, and other official actors”). For environmental disputes, see Benjamin van Rooij \& Carlos WingHung Lo, Fragile Convergence: Understanding Variation in the Enforcement of China's Industrial Pollution Law, 31 LAW AND POL'Y 114, 114-37 (2009) (observing that environmental enforcement patterns vary both over time and by region, and that a combination of institutional factors can account for such variation, including central government support, community pressure, local government commitment, enforcement capacity, regulated firm characteristics, and general economic conditions).

63. See generally Su Li, Guanyu nengdong sifa yu datiaoje [Judicial Activism and Grand Mediation], in 1 ZhongGuo Sifa [ChINA JustiCE] 5-16 (2010); Chen Hanfei and Mou Naidong, "datiaojie" jizhizhong fayuan de juese dingwei [The Role of the Court in Grand Mediation], 11 Xinan Zhengfa DaXue Xuebao [J. Sw U. Pol. \& L.] 128-34 (2009); Li Guanghui and Sun Yongjun, Guanyu datiaojie zhi fa de sikao [Some Jurisprudential Considerations on Grand Conciliation], 18 J. SHANTOU U. 46, 48 (2002).

64. Although organizational structure varies from place to place, in general, grand mediation involves the Party Committee (dangwei), the Politics and Law Committee, the Comprehensive Control Department (zonghe zhili bumen), Social Stability Maintenance Office (weiwenban), the local government, relevant administrative departments (labor, civil affairs, environment, health, etc.), the judiciary, the local justice bureau, the various mediation organizations, other organizations such as letter and petition bureau (xinfangju) and social groups or individual citizens. 
framework that encourages mediation and requires arbitration before parties can access the court and the court's inability to provide an adequate remedy given limited resources, together with a governmentwide campaign to build a harmonious society based on sustainable and equitable development and social justice. ${ }^{65}$ It also reflects the populist turn of the judiciary under the new president of the Supreme People's Court, Wang Shengjun. Wang has called for a more "democratic" judiciary that is responsive to citizen needs, and promoted mediation and settlement of disputes as part of the effort to realize a harmonious society.

The judiciary's response to these labor disputes is part of a longerstanding approach to the dramatic rise in the number of mass plaintiff cases, many of which involve social and economic claims. Given the large number of parties, and often media attention, such cases threaten social stability. In response, the courts have developed a number of techniques to reduce public pressure, including breaking the plaintiffs up into smaller groups, emphasizing conciliation, and providing a spokesperson to meet with, and explain the legal aspects of the case to, the plaintiffs and the media in the hopes of encouraging settlement or even withdrawal of the suit. Some courts also try to pacify the protesters by providing accelerated procedures to access government sponsored funds. To deal effectively with these cases, basic-level courts have found it helpful to work closely with higher-level courts and other government entities, resulting in the recent emphasis on grand mediation.

In a further effort to transform these emotionally charged and highly adversarial lawsuits into a less confrontational process more likely to provide some level of satisfaction to the parties, the All China Lawyers Association issued guidelines that seek to reach a balance between social order and the protection of citizens and their lawyers in exercising their rights. ${ }^{66}$ The guidelines remind lawyers to act in accordance with their professional responsibilities. Lawyers should not encourage parties to interfere with the work of government organ agencies; they should accurately represent the facts in discussions with the media and refrain from paying journalists to cover their side of the story; and they should report to and accept the supervision of the bar association. On the other hand, bar associations shall promptly report instances of interference

65. Su \& He, supra note 3.

66. All-China LaWyers Association, GUIDING Opinion ON LAWYERS HaNDLING Collective CASES (Mar. 20, 2006), available at http://chineselawyer.com.cn. 
with lawyers lawfully carrying out their duties to the authorities, and press the authorities to take appropriate measures to uphold the rights of lawyers. And where necessary, local bar associations may enlist support from the national bar association.

Given the circumstances, an aggressive role for the courts in developing ESR jurisprudence is simply not possible. Chinese courts have exercised, and will have to continue to exercise, caution in handling ESR cases. Like courts everywhere, Chinese courts have at their disposal a number of procedural techniques to avoid being overwhelmed by ESR cases. They can, and have, limited standing, for instance interpreting standing requirements narrowly to prevent "private attorney general" lawsuits, or denied jurisdiction. ${ }^{67}$ They have emphasized mediation. They have found employers in violation in employment discrimination cases but not provided the requested remedy of a job. They have decided for parties in labor dispute cases but limited the remedy to monetary damages, often in an amount less than requested. Citing legal barriers and enforcement difficulties, they have pushed disputes back to political and administrative channels, requiring parties first exhaust their administrative remedies,

67. A Supreme Court training manual suggests some very general guidelines for determining whether a case should be accepted: "The merits of the case by the Courts must be measured against two criteria: (1) legal criterion: whether it falls within the scope of laws and regulations . . . (2) political criterion: for questions that involve national defense, foreign relations, state interest and other matters that go beyond the scope of the power of the judiciary and are not suitable to be adjudicated by the courts, cases should not be accepted. This is dictated by the place of the courts . . . in the political system." HuMAN RightS WATCH, WALKING ON THIN ICE: CONTROL, INTIMIDATION, AND HARASSMENT OF LAWYERS IN CHINA 21 n.50 (2008), http://www.hrw.org/reports/2008/china0408/5.htm (citing Huang Lirong, Guan yu minshi libiaozhun de fali sikao [Legal Theory Considerations on the Standards of Case Filing in Civil Litigation], in GUIDE ON CASE-FILING 89-91 (Office of the Supreme People's Court ed., 2004)). One media report widely discussed on the Internet claims that Guangxi courts would not accept thirteen types of cases including securities litigation, land taking claims and compensation for resettlement, disputes arising out of illegal ponzi schemes and other chain sale scams, cases involving laid-off workers and retraining as a result of economic transition or as a result of bankruptcy, large scale government cancellation of rural responsibility system contracts, and remaining problems regarding how to divide collectively owned assets. Many of the cases fall into the ESR category. Many also involve large multi-party suits. In most if not all cases, the parties would have available a variety of political, administrative and private channels to pursue their claims, each of which has advantages and disadvantages, none of which ensures success. See Guangxi fayuan bu shouli 13 lei anjian; shenggaoyuan cheng you guoqing jueding [Guangxi courts refuse to accept 13 types of cases; High Court claims decision in accordance with national conditions], Zhongguo nianqing bao, Zhongqing zai xian, Aug. 242004. See also Stern, supra note 3 (noting judges routinely refuse filing of environmental cases; they often refuse to provide a written reason despite being required by law to do so, thus preventing parties from challenging the decision; in many cases, they refuse to accept the case because an administrative solution is underway or litigation is not an effective way to resolve the issue). 
while at the same time claiming the right to review the government's decisions in administrative litigation. ${ }^{68}$

Yet a cautious approach alone is clearly inadequate, as evidenced by the ever-increasing number of mass protests, many in response to the failure of the courts to adequately address ESR claims. Thus, in addition to working with government agencies, the judiciary should consider a somewhat more proactive, multipronged approach.

First, drawing on the experiences of courts elsewhere, the Chinese judiciary should focus more on the duties to respect and protect ESR than the more costly and ambitious duty to fulfill. When the state has a clear obligation to individuals, particularly with respect to the core minimum, the judiciary should be more assertive in providing a remedy. For instance, cases suitable for individualized judicial remedy include forced evictions to ensure proper procedures have been followed and adequate compensation has been paid; violations of the prohibition against child labor; some labor cases where the issue is failure to pay wages, wrongful termination of individual employees, or unsafe working conditions, particularly where life threatening; ${ }^{69}$ and the failure to provide emergency medical treatment to protect life rather than turning people away because they have no insurance and cannot pay out of pocket. This will go a long way toward meeting the requirement of protecting the most vulnerable members of society.

Second, the court should be more assertive in enforcing the duty to protect against third parties. For instance, the government has repeatedly issued regulations and notices prohibiting schools from charging fees, thus depriving children of the right to free primary education. In enforcing the government's regulation, particularly against private and for-profit schools, the courts would be enforcing government policies and meeting the legitimate, minimal and essential rights of children to the education

68. See generally He Xin, The Judiciary Pushes Back: Law, Power and Politics in Chinese Courts, in JUDICIAL INDEPENDENCE IN CHINA, supra note 3 (discussing the handling of cases involving "married out women" i.e. women who leave their home village once they are married and then are denied economic benefits from their home village).

69. There are a number of steps that the courts and lawmakers could take to facilitate these sorts of labor claims, such as reducing the barriers to litigation by permitting parties to bypass arbitration, lowering or waiving court fees, improving legal aid, and more aggressively exploiting fee shifting rules to impose costs, including attorney fees, on the employer if a violation is found. See BROwn, supra note 3, at 6-7 (recommending changing the current de novo review of arbitrated labor disputes to a deferral policy that accepts the finality of arbitration, absent a showing of illegality or procedural irregularity, as well as clarification of the definition of "labor dispute" to allow more cases to proceed to direct court review). 
needed to compete equally and become a productive member of society. Similarly, many environmental and labor cases involve violations by third parties, often for-profit businesses.

Third, although the indirect strategy of framing ESR claims in terms of traditional CPR is generally not promising in China given the limits on political lawyering and CPR more broadly, the courts may still be more assertive in developing a jurisprudence of equality and nondiscrimination. The courts have been relatively successful in handling ESR cases based on anti-discrimination principles, although they have been reluctant to order employers to hire the person even when they find a violation. One reason is that the EPL is unclear about remedies. Another is that many of the cases have involved persons applying for civil servant positions, and the court may be reluctant to order local government agencies to take on someone against their wishes. Nevertheless, these cases have had a positive impact in that they attracted media attention and led to legislation to address the problem. The courts could continue to find violations, but leave it to the legislature to address. Alternatively, they might experiment with more robust remedies, including money damages or specific performance in the form of requiring the government agency to offer the next available job to the plaintiff.

Fourth, the court should be more assertive in promoting the procedural dimension of ESR protection. They can use the opportunity provided by such cases to hold government to their commitment to make information publicly available under the national and local freedom of information acts. They can also decide against the government on procedural groundsfor not holding a hearing, denying the parties the opportunity to be heard, failing to obtain or make available to the public a environmental impact study, etc. ${ }^{70}$ In this way, the courts could avoid a direct confrontation with the government agency on the substantive issue, while allowing the government agency the opportunity to correct the procedural shortcomings.

Fifth, with respect to the duty to fulfill, courts should avoid broad remedies, adopt the reasonableness approach, and show deference to other state organs. In terms of remedies, the courts should mainly emphasize declaratory relief. Given their limited powers within the constitutional framework, they simply are not in a position to issue mandatory orders telling the government what to do in most cases with far-reaching economic and social implications. For instance, state-owned enterprise reform and the transition to a market economy have led to many disputes over pension payments and other welfare benefits, including unemployment

70. Cf. Guerra v. Italy, 26 Eur. H.R. Rep. 357, 359-60 (1998) (finding that failure to provide information about pollution from a chemical factory was a violation of ECHR, art. 8). 
insurance, job relocation and training expenses, worker's compensation benefits and medical care. In handling such cases, the court could and should find a violation, but then leave it up to the discretion of the government how best to address the problem where a general policy issue is involved.

In addition, the court could find that the government has failed to develop the program to address ESR as required by law, and if so, request that the government remedy the situation by developing the required program. For instance, Article 25 of the Employment Promotion Law provides "governments at every level shall create a fair employment environment, eliminate discrimination in employment, formulate policies and take measures to support and assist the hard-to-employ., ${ }^{\prime 1}$

Supervisory orders may also be possible in some circumstances, for instance, where the government has established a program. However, it is highly unlikely that the courts will be able to require other government actors to report back on a regular basis. Under the constitution, the people's congress and procuracy are charged with supervising the courts, not the other way around. In recent years, there has been a great deal of tension between people's congress and courts over whether this right of supervision permits individual case supervision. Although the procuracy's right to protest individual cases is clear, the scope of right and the manner in which it is to be exercise are still subject to vigorous debate. Moreover, the general transition to rule of law has increased the authority of courts relative to other state organs, particularly the procuracy and the police. This has led to a certain amount of resentment on the part of the procuracy and police. Accordingly, now would not be a good time to be challenging their authority by issuing supervisory orders that require the procuracy, police, or people's congress to report back to the court on how they are implementing particular policies.

Fortunately, a more positive alternative approach is available. In recent years, there have been local experiments in environmental cases with more relaxed standing rules that allow the procuracy and certain NGOs to bring public interest suits. ${ }^{72}$ Expanding these experiments to allow the procuracy a broader role in representing the public in ESR suits may help defuse the tension between the courts and procuracy, and

71. See Employment Promotion Law (promulgated by the Standing Comm. Nat'l People’s Cong., Aug. 30, 2007, effective Jan. 1, 2008), art. 25 (2008) (China).

72. See Gao Jie, supra note 3, at 8-9 (noting that in Yunnan, only the procuracy and public interest organizations registered in China have standing). 
provide adequate assurance to the government and judiciary alike that the courts will not be inundated by ESR suits.

Similarly, the courts could follow the example of the Indian Supreme Court in asking the procuracy or government agencies to investigate the facts and supervise implementation of court ordered remedies or government programs. ${ }^{73}$ In India, this has helped transform the adversarial litigation process into a more cooperative process, with the government officials who appear in public interest litigation cases seeking to find constructive solutions to pressing problems rather than viewing their role as to defend government policy at all cost. The Indian Supreme Court has emphasized that public interest litigation is "not a litigation of an adversary character for the purpose of holding the State... responsible for making reparation, but it is a public interest litigation which involved a collaborative and cooperative effort ... for the purpose of making human rights meaningful for the weaker sections of the community.,"74

Sixth, in applying the reasonableness standard, the courts should pay particular attention to the minimum core and the most vulnerable members of society. This is not only consistent with the advice of the CESCR, but also reflects the large number of people who are still living in poverty, the high level of inequality, and the negative consequences of economic reforms and rapid social transformation over the last thirty years. Thus, if plaintiffs claim a violation of a minimum core right, the court could shift the burden to the government to prove that it has taken reasonable legislative and other measures, within its available resources, to achieve the progressive realization of the right, and to show that any limitation "is reasonable and justifiable."

Although the reasonableness standard means that the court will not inquire whether there are other more desirable measures that could have been adopted, there may still be a high level of scrutiny of the state's actions and justifications for its actions. In particular, the court should scrutinize with great care government claims of inadequate resources. They may ask, for example, with respect to the rights of migrant workers to education and health whether enough is being done. They may request that the government provide information about the costs of enforcing the right, promote cost-benefit analysis, review budgets, and encourage people's congresses and government agencies to articulate minimal national and local standards so that the courts can effectively evaluate the government's response to plaintiff claims. ${ }^{75}$ They may also

73. Kothari, supra note 42, at 12.

74. Dr. Upendra Baxi v State of Uttar Pradesh (1986) 4 S.C.C. 106 (India).

75. See Colin Harvey \& Eoin Rooney, Integrating Human Rights? Socio-Economic Rights and Budget Analysis, 2010 EUR. HuM. RTS. L. REV. 266, 267, http://ssrn.com/ 
assess the performance of the government against the performance of similarly situated regions by drawing on empirical data and objective indicators. $^{76}$ Of course, cost-benefit analysis, transparent budgetary reviews, objective indexes, impact assessments and the like are also important tools for improving policymaking by the legislature and government agencies, and thus should be seen as part of a broad, less threatening, cooperative effort to govern more rationally, efficiently and equitably.

\section{CONCLUSION}

The PRC government is by no means hostile to ESR per se. Even a cursory glance at China's initial report on the implementation of the ICESCR demonstrates the government's commitment to alleviating poverty, improving living standards and promoting more sustainable and equitable development. Nor is the government opposed to constructive advice from the international community. As noted, the government has developed a national human rights action plan, and formulated many other plans to promote ESR. It has also taken many "deliberate, concrete and targeted" steps to ensure the realization of ESR.

Nevertheless, the judiciary has played a limited role in enforcing ESR, and is likely to continue to do so. In comparison to the courts in many countries, Chinese courts are inhibited in implementing ESR by a variety of factors, among them shortcomings in the regulatory framework including the lack of specific and robust individual remedies in many laws, institutional design that limits the power of the judiciary within the Chinese constitutional structure, political limitations inherent in an effectively single-party social state, ideological conflicts between New Left advocates of socialist justice and New Right proponents of neoliberalism, and resource constraints typical of lower-middle income countries. Even in South Africa, the courts, mindful of the cost implication of their

abstract=1590214 (discussing how courts might use economic techniques to appraise public expenditure in line with international obligations under ICESCR); QUEEN's UNIV. BELFAST Budget Analysis Project, Budget Analysis and Economic and Social Rights: A REVIEW OF SELECTED CASE STUDIES AND GUIDANCE (Oct. 5, 2010), available at http://www. qub.ac.uk/schools/SchoolofLaw/Research/HumanRightsCentre/ResearchProjects/BudgetAna lysis/Documents/filestore/Filetoupload,210765,en.pdf.

76. See generally Sital Kalantry et al., Enhancing Enforcement of Economic, Social and Cultural Rights Using Indicators: A Focus on the Right to Education in the ICESCR, 32 HuM. RTS. Q. 253 (2010). Sakiko Fukuda-Parr et al., An Index of Economic and Social Rights Fulfillment: Concept and Methodology, 8 J. HuM. RTS. 195 (2009). 
decisions, have exercised caution, often finding a violation but allowing the government to figure out what to do about it or providing relief to individual parties but denying relief when a wider class would be affected. ${ }^{77}$

There is no reason to expect that courts will play the same role in all countries, nor is a court-centric approach necessarily the most appropriate or effective way to implement ESR. In China, political and administrative mechanisms have played and will continue to play a more prominent role. $^{78}$ The role of civil society, NGOs, and self-governing private and public-private hybrid regulatory systems are also important complements to the courts. ${ }^{79}$ No doubt changes to the incentive structure for evaluating and promoting government officials, now biased toward economic growth and social stability, would have a more immediate and dramatic impact on the full realization of ESR than all of these other remedial mechanisms combined.

The long-term solution to socio-economic cases is growth, although growth alone is not sufficient. As the government has realized, development raises many social justice issues, including how the wealth generated by

77. In Thiagraj Soobramoney v Minister of Health, KwaZulu-Natal 1998 (1) SA 765 (CC) at 773-75, para. 19 (S. Afr.), involving a claim by a diabetic man in need of dialysis treatment to survive, the Constitutional Court found that the right to "emergency medical treatment" could not extend to life-prolonging treatment for terminally ill patients because such an interpretation would prioritize the health needs of the terminally over the needs of others, given limited state resources. However, it rejected the lower court's order for the state to provide infant formula to poor mothers, which was the most expensive remedy sought. Id. In TAC, supra note 38, at para. 135, the Court ordered the government to lift the prohibition on distribution of a drug to prevent the transmission of HIV outside the pilot program and ordered the government to immediately produce a more expansive national program for the prevention of HIV transmission. However, it rejected the lower court's order for the state to provide infant formula to poor mothers, which was the most expensive remedy sought. Id.

78. While it is difficult, for example, to find a comprehensive study of the role of the courts in enforcing labor rights or protecting workers, there are many books that describe the complex regulatory framework of laws and regulations, the policies and politics of labor laws, administrative mechanisms and political channels for protecting labors, and even social protests. See, e.g., RONALD C. BROWN, UNDERSTANDING LABOR AND EMPLOYMENT LaW in China (2009); William Hurst, The Chinese Worker AFTER Socialism (2009); Ching Kwan LeE, Against the Law: LABOR Protests in ChinA's Rustbelt and SunBelt (2007); Mary Gallagher, Contagious Capitalism: Globalization and the Politics OF CHINESE LABOR (2005).

79. See, e.g., Jin Yanhong et al., Environmental Performance Rating and Disclosure: An Empirical Investigation of China's Green Watch Program (World Bank Dev. Research Grp. Env't \& Energy Team, Working Paper No. 5420, Sept. 2010), http://ssrn.com/abstract $=1678349$ (noting that environmental performance rating and disclosure has emerged as an alternative or complementary approach to conventional pollution regulation, especially in developing countries, the authors provide an empirical study of the impact of one such performance rating and disclosure program in China). 
development is to be distributed. A comprehensive policy approach that goes well beyond judicial remedies is required. ${ }^{80}$

Nevertheless, international experience demonstrates the limitations of implementing ESR without some role for the courts. The key however is to develop a feasible strategy that allows the judiciary to play a constructive role and yet is consistent with the operating environment. While a robust role for an activist judiciary in China may have normative appeal to many, it is not realistic in the current circumstances. Pie-in-the-sky proposals serve a positive function in pressing for a more ambitious agenda, but a piece or two of pie in the belly may be more important to the most vulnerable members of society. A more moderate, gradual, pragmatic approach along the lines suggested herein may lead to better protection of ESR. Over time, the judiciary will accumulate experience and China will continue to develop, thus growing out of many of the problems and providing the courts greater leeway to order costly remedies. The judiciary's role in implementing ESR will therefore need to be continually assessed, updated, and adjusted, with the overall trend being toward a more expansive and assertive role for the courts.

80. See CHINA Modernizes, supra note 1, advocating, inter alia, (1) preventing disputes from arising in the first place by improving the welfare system, and increasing resources to address some of the major social cleavages; (2) developing and strengthening procedural mechanisms to handle the increasingly diverse views in society, and in particular increasing political participation in the decision-making processes, whether through public hearings, consultative committees or participation in the nomination or election of officials; (3) enhancing non-judicial mechanisms for addressing citizen concerns in ESR cases, including administrative reconsideration, the letter and petition system, mediation, arbitration and supervision by the administration, people's congress and Party; (4) improving procedural justice in all mechanisms for resolving disputes, whether through mediation, the letter and visits system, court cases or other means: participants must perceive the mechanisms to be fair, regardless of the outcome in the particular instance; and (5) explaining the proper role and the limits of the legal system and rule of law in resolving these controversial issues. In addition to these general recommendations, specific types of cases give rise to specific issues, and require specific policy responses and reforms. See Yulin \& Peerenboom, supra note 3. For further area-specific proposals, see generally supra note 3. 
